\title{
The Evolution of Power in the Global Coffee Value Chain and Production Network
}

\author{
Grabs, Janina; Ponte, Stefano
}

\author{
Document Version \\ Accepted author manuscript \\ Published in: \\ Journal of Economic Geography \\ DOI: \\ 10.1093/jeg/lbz008 \\ Publication date: \\ 2019 \\ License \\ Unspecified
}

Citation for published version (APA):

Grabs, J., \& Ponte, S. (2019). The Evolution of Power in the Global Coffee Value Chain and Production Network. Journal of Economic Geography, 19(4), 803-828. https://doi.org/10.1093/jeg/lbz008

Link to publication in CBS Research Portal

\section{General rights}

Copyright and moral rights for the publications made accessible in the public portal are retained by the authors and/or other copyright owners and it is a condition of accessing publications that users recognise and abide by the legal requirements associated with these rights.

\section{Take down policy}

If you believe that this document breaches copyright please contact us (research.lib@cbs.dk) providing details, and we will remove access to the work immediately and investigate your claim.

Download date: 26. Apr. 2023

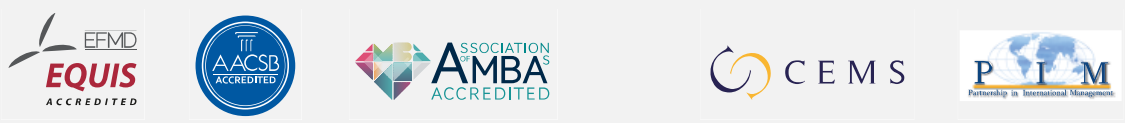




\title{
The Evolution of Power in the Global Coffee Value Chain and Production Network
}

\author{
Janina Grabs and Stefano Ponte
}

Journal article (Accepted manuscript*)

\section{Please cite this article as:}

Grabs, J., \& Ponte, S. (2019). The Evolution of Power in the Global Coffee Value Chain and Production Network. Journal of Economic Geography, 194), 803-828. https://doi.org/10.1093/jeg/lbz008

This is a pre-copyedited, author-produced version of an article accepted for publication in Journal of Economic Geographyfollowing peer review. The version of record is available online at:

\section{DOI: https://doi.org/10.1093/jeg//bz008}

* This version of the article has been accepted for publication and undergone full peer review but has not been through the copyediting, typesetting, pagination and proofreading process, which may lead to differences between this version and the publisher's final version AKA Version of Record. 


\title{
The evolution of power in the global coffee value chain
}

\author{
Janina Grabs and Stefano Ponte
}

\begin{abstract}
The configurations of global value chains is constantly changing, leading to new trajectories and geographical distributions of value creation and capture. In this article, we offer a 40-year evolutionary perspective on power and governance in the global coffee value chain. We identify three distinct phases that are characterized by different power dynamics, governance setups, and distributional configurations. We find that the kinds of power exercised along the coffee chain have changed, but also that the underlying power inequities between Northern buyers and Southern producers have remained fundamentally unchanged.
\end{abstract}

Keywords: Global production networks, evolutionary economic geography, power, distributional configurations, coffee

JEL codes: P16 - Political economy; O20 - General (Development planning and policy); O17 (Formal and Informal Sectors • Shadow Economy • Institutional Arrangements); Q17 - Agriculture in International Trade 


\section{Introduction}

The only constant in life is change. This aphorism from Heraclitus, the pre-Socractic Greek philosopher, is particularly true in today's economic system. Spurred by the globalization of factor and labour markets, firms continuously reconfigure their production arrangements and seek expansion into new consumer markets. Although scholars working in the Global Value Chain (GVC) and Global Production Network (GPN) ${ }^{1}$ traditions have been examining the configuration of global economic activity for decades, there have been few efforts to explain the changes in production systems over time in theoretically robust ways. Rather, the broad majority of GVC and GPN studies "represents an amalgam of 'snapshot' analyses of particular industries and products at moments in time" (Oro and Pritchard $(2011,711-712)$.

As a consequence, chain and network evolution has been relatively undertheorized. This lacuna has been tackled in two main ways. One approach (Oro and Pritchard, 2011; MacKinnon, 2012) has drawn on the emerging field of evolutionary economic geography to specify an evolutionary theory of global value chains. Another (Yeung and Coe, 2015) has built a dynamic theory of global production networks, or 'GPN 2.0'. Both these approaches have their merits, but also ignore a central feature of value chains- the evolution of power dynamics. In this article, we argue that understanding such

\footnotetext{
${ }^{1}$ We recognize that the GVC and GPN traditions developed along distinct paths, the former emerging from sociology and political economy, the latter within the field of economic geography. However, the distinctions between the two traditions have become much less marked in time, and especially in the last decade. A joint workshop in Singapore and the resulting publication in 2014 of a special issue of the Review of International Political Economy, edited by major figures in the two fields, are testimony to this rapprochement. In this article, we distinguish analytically between the two schools when necessary and relevant, but refer to GVCs as an object of analysis that also includes GPNs.
} 
changes through a new typology of power helps to appreciate why in highly unequal value chains upgrading activities by suppliers frequently do not lead to increased value capture (see Gereffi, 1999b; Kaplinsky and Fitter, 2004; Rossi, 2013; Glückler and Panitz, 2016; Vicol et al., 2018).

Through this approach, we seek to bind the concerns of evolutionary economic geography (EEG) (Boschma and Frenken, 2006; Boschma and Frenken, 2009; Boschma and Frenken, 2011) with the more political economy orientation of the GVC and GPN literatures. The logic of this effort emanates from the observation that GVC analysis aims at explaining transformations in the functional division of labour along value chains and its distributional consequences, fitting neatly with EEG's interest in "the processes by which the economic landscape - the spatial organization of economic production, distribution and consumption - is transformed over time" (Boschma and Martin, 2007, 539). As argued by Oro and Pritchard (2011), EEG can contribute a number of key concepts and insights to the conceptualization of GVC dynamics. These include the notions of path dependence, hysteresis, and punctuated equilibria.

Path dependence is defined as a process or system "whose outcome evolves as a consequence of the process's or system's own history" (Martin and Sunley, 2006, 399), and thus draws our attention to early choices that may constrain the later choice sets of economic actors (MacKinnon, 2012). Hysteresis refers to the independent co-evolution of economic actors and the institutions that constrain them due to mutual feedback loops. Hence, institutions are seen as "both endogenous and exogenous to processes of change" (Oro and Pritchard, 2011, 713). Finally, in the short term, it is possible that institutional environments are a mismatch for the "restless dynamics of economic efficiency", leading 
to "periods of stability followed by 'punctuated equilibrium', in which rapid transformations occur as institutional change 'catches up' with latent economic forces" (Oro and Pritchard, 2011, 712). ${ }^{2}$ However, previous attempts at enriching GVC and GPN analyses with EEG were based on an under-conceptualization of power and its role in shaping economic outcomes (Jones, 2008, 72; MacKinnon et al., 2009, 137; Pike et al., 2009, 180).

'GPN 2.0' approaches the dynamism of global production networks from a different perspective. Yeung and Coe (2015) recognize that the question "what accounts for the historic origin and dynamic evolution of global production networks over time?" has been left unanswered by the existing GVC and GPN 1.0 frameworks. To answer it, they take an actor-centred focus toward theory development. They identify both competitive dynamics (optimizing cost-capability ratios, market imperatives, and financial discipline) and risk environments (including economic, product, regulatory, labour and environmental risk) that will influence actor strategies. In constructing their "coherent conceptualization of causal mechanisms", they identify "structural dynamics as causality and firm-specific strategies as mechanisms" (Yeung and Coe, 2015, 33). Yeung and Coe (2015)'s ultimate dependent variable is development outcomes (including industrial upgrading, sectoral transformation, and local and regional development). Yet, when examining the interaction between structures and economic agency, their explanatory

\footnotetext{
${ }^{2}$ It should be noted that while this approach opens up interesting avenues of inquiry, its strong focus on institutions is a departure from traditional EEG. Indeed, the relative importance of institutions and their theorization continues to be one of the strongest point of contention among critics and proponents of evolutionary economic geography, especially as they aim to distinguish this approach from institutional economic geography (Boschma and Frenken, 2006; Boschma and Frenken, 2009; MacKinnon et al., 2009; Pike et al., 2009; Hassink et al., 2014).
} 
framework takes little heed of ways in which value creation and capture continues to be skewed toward certain actors in the value chain. For instance, they identify the creation of new markets as a possible win-win strategy for both buyers and manufacturers of goods and services, given that "access to markets in advanced economies through lead firms brings potentially larger orders, upgrading opportunities, and, ultimately, better value capture" to suppliers (Yeung and Coe, 2015, 38). But an increasing number of studies have found that despite producers' best efforts, upgrading often fails to lead to improved value capture and regional development (Ponte and Ewert, 2009; Selwyn, 2012; Werner, 2012; Tokatli, 2013; Smith et al., 2014; Selwyn, 2015).

In this article, we argue that a conceptualization of power in GVCs that is both multifaceted and dynamic is crucial to explain whether and how firm- or country-level actions (e.g. product upgrading) may lead to improved development outcomes. ${ }^{3} \mathrm{We}$ furthermore showcase the usefulness of EEG concepts to explain these dynamic changes in the coffee sector. Path dependence can explain why certain types of power constellations continue to reproduce, to the detriment of weaker actors. The concept of punctuated equilibria can explain why rapid shifts between one type of power, or group of powerful actors, to another occur. Finally, we demonstrate that the type of power exercised in GVCs may co-evolve with economic actors' strategies while maintaining existing hierarchies and distributional outcomes. We see this hysteresis of power relations as a further effort in

\footnotetext{
${ }^{3}$ Glückler and Panitz $(2016,1163)$ make a similar argument regarding the importance of relational ties, noting that "improving an activity does not necessarily correspond with a better position in the value chain, additional value or progress in regional development". However, their analysis still focuses narrowly on a firm's position in the overall value network rather than on the range of ways in which power can be exercised in global production networks, as we do.
} 
modular theory-building (Ponte and Sturgeon, 2014) that has the potential to inform and strengthen the GVC and GPN literatures.

Building on the existing evolutionary and dynamic approaches in GVC and GPN analyses (Oro and Pritchard, 2011; MacKinnon, 2012; Yeung and Coe, 2015), and drawing from the coffee GVC, this article provides two contributions. First, it applies a recentlydeveloped typology of power, which distinguishes between bargaining, demonstrative, institutional and constitutive power, to determine the specific characteristics of different periods of value chain governance and their distributional effects. Second, it assesses whether new governance arrangements have fundamentally shifted power constellations towards Southern producers in view of rebalancing the socio-spatial distribution of value and risk. ${ }^{4}$

The recent dynamism in the organization of the coffee GVC makes our sectoral focus particularly relevant. The past five years have seen a period of re-consolidation among large roasters that analysts are calling a 'sudden shift in the coffee landscape' (Watson, 2017). This is manifested in the increasing pace of acquisition among coffee roasters, and is also driving a wave of consolidation upstream among international traders as they come under renewed financial pressure from roasters (Grabs, 2017). ${ }^{5}$

\footnotetext{
${ }^{4}$ It should be acknowledged that different production origins will encounter a variety of context conditions that will also affect their possibility to accumulate value, such as scale, institutional context, local producer profiles, local industry structure, etc. While recognizing such diversity on the ground, and drawing attention to it where applicable throughout the text, we here primarily focus on global shifts in power dynamics that will create different opportunities or barriers for countries to draw on their specific contexts for improved value distribution.

${ }^{5}$ Indeed, these developments reflect a broader trend toward consolidation in other agri-food sectors. The food industry represents a disproportionally high share of mergers and acquisitions activity both by numbers of transactions and by volume (Adams et al., 1997; Adelaja et al., 1999; Muehlfeld et al., 2011). Drivers of this trend include the financialization of commodity markets (Newman, 2009), strategic shifts toward more flexible and agile portfolio management among multinational companies (Bloomberg News, 2016), and the
} 
Simultaneously, new markets are emerging, industry organizations have been dissolved while others are being newly founded, new trends are arising in high-quality coffee, and NGO engagement strategies are shifting from opposition to collaboration with large multinationals (Grabs, 2018).

On the basis of two decades of research in this field -including long-term fieldwork in the early 2000s and late 2010s, expert and key informant interviews, document analysis of industry reports, and participant observation at several coffee industry meetings in consuming and producing countries - we identify and analyse three historical phases in the governance of the coffee GVC during the post-WWII period. First, in the 'ICA phase' (1962-1989), international trade coffee was governed by the International Coffee Agreement. Second, the post-ICA 'liberalization phase' (1989-2007) is defined by the abolishment of the formal regulatory infrastructure and the slow rise of market-driven differentiation along quality and sustainability characteristics. Third, the 'diversification and reconsolidation phase' (2008-present) is characterized by a portfolio-based reconsolidation of large roasters, their increasing use of traceability tools for supply chain management, the related decline of sustainability premiums and rise of quality expectations, and a recent movement by producing country actors to counter the renewed power of large roasters. By documenting the various shifts in the types of power relations that gradually took place in these three phases, we show that the transformation of coffee from a relatively uniform product to a product with highly differentiated and complex

rising interest of large-scale investors, who are betting on the global rise of the middle class, in recessionproof consumer goods (Gara 2015). 
quality profiles has not resulted in a radical socio-spatial redistribution of value along the chain.

\section{Analytical framework}

\subsection{Power in GVCs}

As highlighted in Dallas et al. (2017), power is an "essentially contested" concept (Gallie, 1956) in the broader political science and political economy literature. Few authors agree on what a notion of 'power' should include or exclude; and so a wide range of 'faces of power' have been identified, ranging from (what might be described as) ${ }^{6}$ resource power (Dahl, 1957), agenda-setting power (Bachrach and Baratz, 1962), ideological or structural power (Lukes, 1974), and discursive power (Digeser, 1992). Relatedly, and focusing on corporate power in agri-food governance, Clapp and Fuchs (2009) distinguish between instrumental power, or direct influence; structural power, or the broader influence corporations have over setting agendas and rules; and discursive, or communicative and persuasive, power.

Yet, the literature in the GVC tradition (Gereffi, 1994; Gereffi, 1999b) has typically limited itself to focusing on the uneven bargaining relationships between firms in international commodity chains, especially between lead firms and suppliers (Dallas et al., 2017). ${ }^{7}$ This falls into the category of 'coercive power', in which one actor utilizes

\footnotetext{
${ }^{6}$ These categories draw on Dallas et al. (2017). It should be noted that the cited authors do not necessarily use this exact jargon to describe their own work - in part because some understand their version as simply the embodiment of 'power' itself as a singular concept.

7 This is explicit in the approach to GVC governance as 'linking' (Gereffi et al., 2005), but also in most of the work on GVC governance as 'driving', where bargaining power is equated with 'drivenness' or 'levels of driving' (Gereffi, 1994; Gibbon et al., 2008). Demonstrative power has not been explicitly considered, with the exception of some micro-level work drawing from convention theory in relation to product quality
} 
incentives or sanctions directly to compel another actor to act according to their wishes (Gereffi, 1994), and in the above distinctions might be most closely related to resource or instrumental power.

There are two connected ways to operationalize such coercive power in the GVC world: first by identifying which supply chain actors 'drive' commodity chains, and second by examining how supply chain actors link to and interact with one another. Gereffi (1994, 1999b)'s seminal work distinguished between producer-driven and buyer-driven commodity chains, describing the latter as "industries in which large retailers, marketers, and branded manufacturers play the pivotal roles in setting up decentralized production networks in a variety of exporting countries, typically located in the third world" (Gereffi, 1999b, 41). Studies that have applied the GVC approach to the coffee industry concur that the buyer-driven typology clearly fits the case (Fitter and Kaplinsky, 2001; Ponte, 2002; Daviron and Ponte, 2005; Ponte and Gibbon, 2005; Bitzer et al., 2008; Bamber et al., 2014).

Gereffi et al. (2005)'s typology of global value chain governance shifted its focus from the more intentional 'driving' to a more dynamic theory of 'linking' supply chain actors (Gibbon et al., 2008). This governance theory identified three key conditions (transactional complexity, codifiability of information and supplier capability), which could be used to distinguish between market, modular, relational, captive, and hierarchical

(Ponte and Gibbon, 2005). Institutional power has been handled mostly under the rubric of 'institutional framework' (Gereffi, 1994; Neilson and Pritchard, 2009; Jespersen et al., 2014) - leading to criticism that these aspects are not integrally embedded in the study of GVC governance (Coe and Yeung, 2015). Constitutive power, when considered at all, has been mainly examined under the rubric of financialization and other perceived 'best practices' in corporate conduct (Gibbon and Ponte 2005; Milberg and Winkler 2013). 
governance. The degree of explicit coordination - increasing as we move from one mode of governance to the next - is inversely related to the magnitude of power asymmetries among the transacting parties. Thus, on the one extreme, market coordination (with the lowest degree of explicit coordination) is characterized by low power imbalances; on the other extreme, hierarchy is defined by total control, thus the highest level of power asymmetry (Gereffi et al., 2005). Yet, this particular approach to power - centred on the ability of lead firms to determine the functional division of labour along a value chain through the exercise of buyer power - fails to acknowledge the existence of other kinds of power in global economic systems. Indeed, it is often in periods of economic liberalization and the prevalence of market coordination that we see growing degrees of concentration in certain segments of a value chain - resulting in more unequal power dynamics. Such cases - as is the case in the coffee sector - need to be better explained.

A possible source for new ways of thinking about power in global production is the so-called 'Manchester School', with its relational conceptualization of economic sectors as complex Global Production Networks (GPNs). The GPN approach calls for more explicit attention to both economic and non-economic actors, and for more focus on economic actors' institutional embeddedness (Henderson et al., 2002; Hess and Yeung, 2006; Coe et al., 2008; Coe and Yeung, 2015). Consequently, most authors following the GPN approach use an actor-based typology of power, differentiating between corporate power ("the extent to which the lead firm in the GPN has the capacity to influence decisions and resource allocations - vis-à-vis other firms in the network - decisively and consistently in its own interests" (Henderson et al., 2002, 450)), institutional (largely 'state') power, and collective (non-firm, non-state) power (Henderson et al., 2002). Yet, they do not specify the possible 
avenues and strategic pathways that would tackle excessive corporate power. Even in the more dynamic GPN 2.0 framework, power continues to be defined as "the capacity of an actor to exercise and achieve control over a particular strategic outcome in its own interests" (Coe and Yeung, 2015, 66), without going into specifics on how such capacity is attained. Furthermore, GPN 2.0 still focuses on instances where actors have direct control over clearly-defined outcomes. Thus, it does not consider alternative types of power, such as the power exerted by collectives of actors where membership boundaries are permeable and thus difficult to conceptualize as an 'actor' that intentionally pursues well-defined outcomes.

These conceptual gaps in both the GVC and GPN traditions are particularly important because they inform the fundamental question of what GVC dynamics and conditions may lead to higher value capture and to development by producing-country actors. A number of efforts have been carried out to explain the gap between producing firms' upgrading activities and their lack of value capture. Some have focused on the role of quality conventions and sustainability standards (Ponte and Gibbon, 2005; Nadvi, 2008; Ouma, 2010); others have leveraged governmentality (Gibbon and Ponte, 2008; Raj-Reichert, 2013; Ouma, 2015) and neo-Gramscian approaches (Levy, 2008; Bair and Palpacuer, 2015; Levy et al., 2016) to illustrate the importance of more ideational forms of governance; and the 'relational turn' of the GPN tradition has led to a focus on "strategic coupling" and the establishment of relational ties for successful upgrading (Coe et al., 2004; Yeung, 2009; Glückler and Panitz, 2016). To clarify and enrich these insights, we draw on Dallas et al. (2017)'s typology of power to demonstrate that a framework of multifaceted and dynamic 
supply chain power is a useful building block for the continued theorization of GVC trajectories.

\subsection{A typology of power in GVCs}

To apply a more expansive notion of power that goes beyond dyadic bargaining between firms, we adopt Dallas et al. (2017)'s typology of power in GVCs along two dimensions: an arena of actors engaged in exercising power (dyads or collectives); and a transmission mechanism (direct or diffuse).

An 'arena' is where specific actors or collectives engage with other actors. In this framing, the arena defines the potential constellation of actors that face each other and exert power over one another. These can either be dyadic (one-on-one interactions of specific firms) or collective (where groups of actors interact with each other). The dyadic arena is tied to the traditional, coercive notion of power relations (i.e. Dahl's (1957, 202-3) definition where "[Actor] A has power over B to the extent that he can get B to do something that B would not otherwise do") and to previous GVC and GPN (1.0/2.0) approaches which focused on relative bargaining power. The collective arena, however, is defined as a "locus of power [that] is a function of the collective behaviours of multiple players acting simultaneously (intentionally or not) and/or of more institutionalized collectives such as business associations, multi-stakeholder initiatives, or states" (Dallas et al., 2017, p.12).

A 'transmission mechanism' differentiates whether power is spread through more direct or diffuse channels. This is linked to whether the actor or collective wielding power can be easily identified and whether the use of power is intentional and directed. In 'direct' power, it is straightforward to determine the actor or collective that holds power; the 
powerful actors' goals are well-known; power is exercised in intentional ways; and it usually includes measuring and monitoring the behaviours of actors over whom influence is exerted (Dallas et al., 2017). In contrast, 'diffuse' power involves influence that spreads in unconscious, decentred, and often demonstrative ways; it may include unintended behaviours and outcomes; and often comes to the fore as broad societal trends, "best practices', or dominant quality conventions (Gibbon and Ponte, 2005).

This two-by-two matrix (see Table 1) yields us four ideal types of power that are exercised in GVCs: bargaining power (direct/dyadic), demonstrative power (diffuse/dyadic), institutional power (direct/collective) and constitutive power (diffuse/collective) (Dallas et al., 2017). These types are not mutually exclusive; on the contrary, they can overlap, combine, and influence each other, as we will see in the case study of coffee.

[Table 1 about here]

Bargaining power (direct/dyadic) is the most common form of power recognized in GVCs and usually refers to dyadic firm-to-firm linkages between buying and supplying firms, and is similar to 'lead firm power' in traditional GVC approaches. It is analysed through dyadic bargaining 'snapshots', even if the total arena of (firm) actors might be wider, for instance if a supplier sells to several lead firms. Inter alia, relative bargaining power depends on the lead firm's production expertise, control over distribution channels, design, and customer relationships in end markets. However, as noted, bargaining power can itself be shaped by one or several other types of power. 
Demonstrative power (diffuse/dyadic) refers to the effect that a firm's relationship with a supplier has in influencing the behaviour of other suppliers and would-be suppliers without the firm exerting direct power over them. This may include, for instance, the transmission of new requirements or preferences, leading to a particular type of upgrading that "may induce adaptation among competing suppliers, or among suppliers wishing to compete in the future" (Dallas et al., 2017, 15) out of fear of otherwise being excluded from GVCs.

Institutional power (direct/collective) is exercised by formally organized collectives such as business associations, multi-stakeholder initiatives, or within the state. Rather than stemming from resources controlled by a single organization, like bargaining power, institutional power is dependent on the strategic actions of groups of actors, or on compliance with the rules set by these actors. Hence, institutional power can be weakened if the group of actors exhibits significant collective action problems. Finally, this type also interacts with clear-cut bargaining power, given that specific actors may draw on market power and firm-specific resources to reach agreements within these groups that are more beneficial to their individual goals.

Finally, constitutive power (diffuse/collective) manifests itself in collective arenas without an institutionalized focal point that directs influence. Instead, it stems from individuals and groups acting in an uncoordinated, but collectively powerful manner - for instance, by providing a growing demand for a certain product or by acting in accordance with existing or emerging norms. As Dallas et al. $(2017,17)$ note, however, "actors still know and agree when a general norm or convention has been violated and sanctions are often collectively imposed, though again enforcement is decentralized and often subtle and 
nuanced compared to the pre-ordained arbiters and judges that may be used in institutional power".

Examining how these four types of power are exercised in different GVC configurations over time allows us to gain a more differentiated understanding of tensions and structural asymmetries, even if they are not directly reflected in coercive bargaining power.

\section{Methods}

Our findings are based on a longitudinal analysis of primary and secondary sources, existing publications on the coffee GVC and its organization (Talbot, 1997; Fitter and Kaplinsky, 2001; Talbot, 2004; Bitzer et al., 2008; Bamber et al., 2014), interviews and fieldwork carried out by one of the authors in the early 2000s (references withdrawn), and the analysis of industry reports, newspaper articles, company websites and other relevant documents. One of the authors also conducted 65 semi-structured expert interviews in the period 2015-2018 with a broad range of participants in the coffee GVC (see summary in Table 2).

[Table 2 about here]

One of the authors also attended several high-level coffee industry events at various levels of organization over the period of $2015-2017 .{ }^{8}$ These events provided a suitable setting to

\footnotetext{
${ }^{8}$ These included the Semana Internacional de Café, a meeting point for large-scale coffee stakeholders, roasters and traders, in 2015 and 2016; the 2016 Forum of the Specialty Coffee Association of America, a
} 
observe intra-industry dynamics and allowed for many opportunities for informal dialogue with industry members. Their attendance was embedded in a larger data collection effort on field-level impacts of sustainability certifications in three Latin American countries that included a significant number of additional conversations with coffee farmers on their views of the industry and its development. This combination of approaches allowed for the triangulation and continuous refinement of results, and a multi-sourced approach to the evolutionary dynamics of the coffee GVC and its power structures.

\section{The evolution of the coffee GVC and its power structures}

\subsection{Three evolutionary phases of the coffee GVC}

Three distinctive phases characterize the evolution of the coffee GVC and its governance in the post-WWII period: the 'ICA regime' phase (1962-1989); the 'liberalization' phase (1990-2007); and the 'diversification and reconsolidation' phase (2008-present). The first, ICA regime phase corresponds to the time (1962-1989) when the International Coffee Agreement (ICA) was in force, which governed coffee supply in the marketplace through a sophisticated quota system. The ICA lapsed in 1989, ushering in a period of deep liberalization of the coffee market with long periods of low and volatile prices that saw producing countries struggle to adjust to new realities. These recurring crises spurred civil society action, both through advocacy campaigns (for instance by Oxfam) and through the establishment of alternative markets such as Fairtrade. At the same time, a reorientation of

gathering of specialty coffee actors; the first General Assembly of the Global Coffee Platform, an incipient platform aiming to become the central unifying force for large-scale sustainability efforts; and the first World Coffee Producers' Forum, organized in 2017 in Medellin, Colombia. 
consumer preferences took place, initiated by the rise of Starbucks and similar coffee shops that sold coffee beverages of increasing sophistication - leading Ponte (2002) to identify an incipient 'latte revolution'.

The third, diversification and reconsolidation phase, which started around 2008 with the financial crisis and continues today, is marked by a new wave of restructuring of coffee roasters that has reverberated across the entire industry. In contrast to the previous transition (at the end of the ICA), the main impetus in this transition has come from value chain actors themselves. During a first period (around 2008 - 2012), in response to a general economic slowdown, the diversified multinationals that had previously held great market power sold or spun off their coffee portfolios amidst the global recession and a general slow-down in the sector. During a second period, from 2010 to 2014, the explosive growth of the specialty and 'Third Wave'9 sector allowed companies such as Starbucks and Keurig Green Mountain, as well as smaller boutique roasters, to increase their market shares (Trefis Team, 2014a; Trefis Team, 2014b). As the economy recovered from 2012 onwards, and the new consumer segment of 'millennials' acquired more spending potential, the coffee market - and in particular its specialty segment - was recognized as an strategic long-term investment opportunity for private equity firms such as JAB Holding (Gasparro, 2015). ${ }^{10}$ This initiated a re-consolidation movement at the end of which almost

\footnotetext{
9 'Third Wave' coffee refers to a sectoral movement that places a strong emphasis on high-quality coffee and considers coffee an 'artisanal' item, similar to wine, rather than a mass consumption good. It values great care and effort in all steps of the production process, from growing over processing to 'micro-roasting' small batches of coffee (this itself is a reference to the micro-brewing of artisanal beers). Its name was coined by US artisanal roasters who consider the dominance of uniform, mass-produced national brands such as Folgers the first wave of coffee culture; the rise of Starbucks and consumer preference of similar espresso-based drinks the second wave; and see the growing appreciation for single-origin, high-quality beans as the next 'wave' in consumption trends (Gold 2008).

${ }^{10}$ In a first step, JAB Holding Co. acquired D.E. Master Blenders and merged it with Mondelez Intl., creating Jacobs Douwe Egberts (JDE), the second largest coffee roaster globally after Nestlé (Armstrong 2014).
} 
all top roasters in 2014 were newcomers to the industry (compare Figure 1; numbers in parentheses reflect global coffee retail market shares in 1998 and 2014).

[Figure 1 about here.]

Nestlé, after years of relatively unchallenged market leadership, suddenly had to face a serious contender for global dominance in JAB Holding (Gretler, 2015; Key, 2015). This battle for market dominance also reverberated across the industry, causing other roasters to strengthen their own portfolios (Landini and Clarke, 2016). It further led to greatly increased price pressure on green coffee, and pressure on all upstream actors, in particular growers and traders, to work on slimmer margins. Building on Ponte (2002), Tables 3 and 4 summarize the main characteristics of these three phases, adding detail for the interested reader.

[Table 3 about here.]

[Table 4 about here.]

\subsection{Changing power constellations in the coffee GVC}

In order to understand the role of power dynamics in shaping GVC restructuring and distributive outcomes, in this section we examine how four types of power (bargaining,

Subsequently, it went on a virtual buying spree, acquiring Peet's Coffee \& Tea, Caribou Coffee Co., Intelligentsia, Stumptown Roasters and finally Keurig Green Mountain on its quest to establish a coffee empire spanning the different consumer segments that had emerged in the previous 10 years (Cohen, 2015). 
demonstrative, constitutive, and institutional power; see Table 1 above) have evolved and interacted throughout the three phases defined in the previous section.

\subsubsection{Power in the ICA phase $(1962$ - 1989)}

As already denoted by its name, the ICA phase was highly influenced by a central arrangement - the International Coffee Agreement - which influenced the actions of almost all actors within the coffee GVC. A typical example of institutional power, the ICA aimed at preventing oversupply and maintaining coffee prices within an acceptable price band and tasked the International Coffee Organization (ICO) to distribute export quotas between producing countries. Under the ICA, collective power relations were relatively balanced between producing and consuming countries, thus strengthening the bilateral bargaining power of suppliers over coffee buyers (Talbot, 2004). Strong local institutions were necessary to coordinate quota distribution and oversee production processes, leading to the strengthening of marketing boards, 'coffee institutes' and other sectoral parastatal organizations. Although there were problems with this system, most analysts agree that it was successful in raising and stabilizing coffee prices (Talbot, 1997; Bates, 1999; Talbot 2004; Daviron and Ponte, 2005).

However, within some producing countries, local regulatory systems allowed for rent-seeking behaviour and the prioritization of certain producers (e.g. large-scale landowners) over others (such as smallholders and marginalized, indigenous communities). Hence, the relative position of smallholder producers also depended on local power relations within the implementing institutions, alongside the broader political orientation of the regime in political power. In other words, while the ICA system worked 
to the advantage of producing countries, this did not necessarily translate into better outcomes at the farm-level, and especially among smallholders.

In this early period, the demonstrative power of roasters furthermore prevented a large-scale differentiation movement in coffee. Mainstream roasters up to the late 1990s, particularly in the United States, were selling large quantities of relatively homogeneous and undifferentiated blends of mediocre to poor quality. This focus can be explained by a historical path dependency from as early as the post-World War I period, when major regional US coffee roasters such as Folgers, Hills Brothers, and Maxwell House were acquired by food conglomerates, became national in scope, and lost their prioritization of localized taste preferences (Pendergrast, 2010; Luttinger and Dicum, 2011). During this upscaling process, first-mover coffee roasters moved away from a focus on quality and locality and started to concentrate on consistency in price, packaging and flavour followed by their competitors.

The aggregate result of these trends was the emergence of a more diffuse form of constitutional power, based on a collective understanding that justified roasters homogenizing blends, using cheaper beans and cutting down roasting times to reduce weight loss and mask the poor quality of the beans. Overall coffee quality decreased. As brand competition took the fore in corporate strategies in the US, the product itself became of secondary importance (Pendergrast, 2010). Homogenization and mass marketing of coffee further increased with the gaining importance of instant coffee after World War II. By competing almost exclusively on advertising, the major roasters stripped coffee of most of its charm and appeal. On the other hand, in Europe coffee standards remained higher 
due to cultural factors and different patterns of consumption even after multinationals moved into the coffee market (Luttinger and Dicum, 2011).

\subsubsection{Power in the liberalization phase $(1989-2008)$}

The end of ICA and erosion of the International Coffee Organization's institutional power led to a general weakening of bargaining power by producing countries and their producers to the benefit of consuming country-based operators (including their agents based in producing countries). The subsequent dismantling of coffee boards, institutes and other quasi-governmental bodies that regulated export sales in many countries decreased the capability of producing countries to control exports and build up stocks. Due to these factors, the average real indicator coffee price in the wake of the ICA's demise (1990-93) was only $42 \%$ of the average price of the final four years of ICA activity (1985-88) (Ponte, 2002). In addition, the producer share of the total coffee income along the value chain dropped by one third, from an estimated $20 \%$ in $1971-88$ to $13 \%$ in $1989-95$ (Talbot, 1997).

In the following two decades, the increasing concentration in the roasting and trading functions of the coffee GVC compounded this dynamic (Daviron and Ponte, 2005).

At the same time, Starbucks and other pioneer specialty roasters started to have a demonstrative effect that led to a massive transformation of parts of the industry, with the emergence of 'sustainable coffees', single origin coffees, the proliferation of café chains and specialty shops, and increasing out-of-home consumption. Starbucks, for instance, pioneered the partial de-commoditization of coffee through educating consumers on the qualities of fine coffees, combining 'ambience' and the possibility for consumers to choose type, origin, roast, and grind, and hence selling coffee 'pre-packaged with lifestyle 
signifiers' (Luttinger and Dicum, 2011, 153). It was also one of the early movers in terms of purchasing certified sustainable coffee and later on, in 2002, developed its own sustainability criteria, the Coffee and Farmer Equity Practices (C.A.F.E.) program, which include quality requirements as a sine qua non condition for participation. Other roasters, such as Nestlé with their Nespresso AAA program, following suit. The rise of microroasters in the quality market, in turn, has spurred innovation in the definition and detection of high-quality coffee, culminating in the Q-grading certification system (established in 2003), which teaches the 'art of cupping' to determine specific flavour notes and awards quality scores on a 100-point scale.

Collectively, the general understanding of what constitutes 'proper' coffee consumption and sustainable production changed dramatically, a sign of transformation in constitutive power, with more consumers expecting to be able to choose from (and pay dearly for) hundreds of combinations of coffee variety, origin, roasting, brewing methods, flavouring, packaging, sustainability 'content', and ambience. The emergence of the 'specialty' coffee market since the late 1980s and early 1990s held a possible challenge to the dominant bargaining power of roasters, at least for a period (Fitter and Kaplinsky, 2001). In the specialty coffee market, especially the part that is operated by independent, smaller-scale roasters and coffee bars, the bargaining power of roasters and coffee shops is indeed less strong vis-à-vis traders and farmers and their cooperatives. For one, in order to gain access to 'exclusive' coffees with unique flavour profiles, many smaller specialty roasters engage in direct trade with cooperatives, shortening the supply chain by cutting out most intermediaries and building multi-year relationships (Wilson and Wilson, 2014; MacGregor et al., 2017; Vicol et al., 2018). This avenue is supported by ICT 
advancements, as social media platforms and internet direct sales have made it easier for smaller roasters to order low-volume batches of specific coffees from dedicated farms and cooperatives in producing countries. Furthermore, coffee excellence competitions and specialty auctions have raised the profile and market clout of producers in this segment (Wilson and Wilson, 2014; Grabs, 2017).

The heterogeneity and polycentric nature of 'specialty coffee' also opened up avenues for Southern actors to co-define novel coffee products that may appeal to Northern consumers, lending them limited constitutive power. An extreme example is the Indonesian kopi luwak coffee, whose special attribute is that it has been fermented through digestion by the Asian palm civet (a type of weasel); but there are also other initiatives by innovative growers such as carbon-neutral coffee, coffee produced only by women, only by indigenous communities, or coffee from particular micro-regions which have attained geographical indications or denominations of origin. In these niche markets, value is usually more equally distributed within the value chain. This provides producer organizations with opportunities to set themselves and their micro-regions apart as highly sought-after origins, and leverage relative scarcity and the higher willingness-to-pay of high-end consumers to achieve prices that lie well above stock-market prices. However, similar to rent-seeking during the ICA quota regime, these benefits may be captured by local elites who consolidate their social positions, reproducing local patterns of inequality (Vicol et al., 2018).

Furthermore, what product becomes successful in the marketplace in practice still depends upon (mainly Northern) consumer preferences and value judgments, which in turn are highly influenced by roasters and other market actors with large marketing budgets. 
Advances in this area run along a strong North-to-South transmission vector, with a narrow group of Northern actors determining both the definition of coffee quality (including the desired sustainability characteristics) as well as the operationalization and measurement of such effects. While there have been efforts to teach Q-grading to producing-country actors to allow them to monitor their quality, the ultimate grading and purchasing decision in the specialty market is made by buyers on the basis of post-harvest samples. It is thus subject to idiosyncratic and subtle trends in preferences that are difficult for producers to anticipate or react to, given that the next year's 'hot trend' may be a different micro-region, varietal, sustainability trend, or flavour mix. This makes specialisation in high-quality coffee a risky strategy for producers who remain highly dependent on Northern buyers' demonstrative power in determining which 'specialty coffee' will be rewarded with premium prices. Similarly, such producers become increasingly dependent on specialty buyers' sourcing strategies, which may be fickle and subject to larger market dynamics - as the next phase will show.

\subsubsection{Power in the diversification and reconsolidation phase $(2008$ - present $)$}

The recent consolidation and related changes in market organization still sees roasters as dominant members of the GVC as they maintain strong bargaining power vis-à-vis both retailers (mainly through large brand investments) and multinational traders (for instance through increasingly stringent financing terms). ${ }^{11}$ In the past decade or so, large traditional

\footnotetext{
${ }^{11}$ In the fight for market dominance and lower margins, roasters owned by investment funds have started to unilaterally extend their net financing terms with traders - the time permissible to pay for their product from an industry standard of 30 days to up to 120 days (Cohen, 2015). According to recent reports, as of 2018 the net financing terms have been increased even further to 360 days. This move has increased traders' required capital stocks and forced them to extend their credit lines, in effect serving as cheap sources of
} 
roasters have also made massive investments in recapturing at least part of the high-margin specialty market, in the process bringing their large market power to bear on it. Nestlé, for example, has aggressively developed its high-end single-serve capsule Nespresso line, while Starbucks has now grown to become the sixth largest roaster globally. Other major roaster groups have been acquiring specialty roasters at a high speed: JDE, for example, acquired Peet's Coffee in 2012; its holding company (JAB) took over Keurig Green Mountain coffee in 2015. As they aim to scale up their performance in this lucrative sector, roasters frequently adopt top-down sourcing management schemes that negate the aspirational equal-footed relations pursued in relationship coffees. For instance, the sustainability verification systems used by Starbucks and Nespresso allow them to obtain precious information on suppliers' cost structures as well, thus strengthening roasters' bargaining power and ability to extract value in higher-margin markets (Muradian and Pelupessy, 2005; Elder et al., 2014; Grabs, 2017; Ponte, 2019).

In addition, during the market downturn following the Great Recession of 2008, several specialty buyers switched their sourcing practices, leaving suppliers in the lurch. Starbucks, for instance, pulled out of higher-cost origins such as Guatemala and Costa Rica and pivoted toward sourcing greater quantities from lower-cost origins such as Colombia and Brazil. Coffee producers in the former countries which had been influenced by Starbucks and undergone the demanding C.A.F.E. Practices verification to become a preferred supplier were thus left with a worthless certification, sunk investment costs and a cautionary tale of blindly following marketing trends.

capital for roasters - a function which many smaller and regional traders could not serve. This in turn contributes to the dominance of few multinational traders. 
At the same time, and despite the widespread dismantling of coffee institutions, several important countries have bolstered their institutional power by supporting their coffee value chains through enforceable (Colombia, Costa Rica, Cote d'Ivoire) or suggested (Brazil) minimum prices for export contracts. Some countries still operate export auctions (Kenya, Tanzania, Ethiopia) and regulate export quality and/or require licenses for exporters (Lora, 2013; Grabs, 2017). Several other support mechanisms are being applied, such as price stabilization funds, disease prevention support and producer income assistance, support for the development of geographic indications, and programs targeting improvement in quality and sustainability. These steps thus curtail some of the bargaining and demonstrative power otherwise exercised by large-scale traders and roasters through public intervention. ${ }^{12}$

This slow renaissance of institutional involvement and power in the coffee value chain culminated in the 2017 World Coffee Producers' Forum, convened by the Colombian Federation of Coffee Producers, which openly discussed the inadequacy of current marketbased price discovery mechanisms in generating prices that cover producers' production costs, and called for an investigation of price and cost trends - along with the determination of a sustainable minimum price. Industry insiders see these steps as possible precursors to renewed attempts to align producing country strategies, especially as production is getting increasingly concentrated in three origins (Colombia, Brazil, and Vietnam). However,

\footnotetext{
${ }^{12}$ This expansion of institutional support may be examined in the context of the 'return of the state' under 'post-neoliberalist' governments, particularly in Latin America. Such a viewpoint highlights that these reformist policies frequently show ambiguity in goal-setting, given many countries' high dependence on agro-exports, alongside institutional lock-ins and path dependencies from previous policy choices (Grugel and Riggirozzi, 2012; Yates and Bakker, 2014). Thus, institutional efforts for instance in Brazil or Vietnam tend to focus more on streamlining and technifying local production, with less attention to value redistribution at the farm (or farm worker) level.
} 
institutional strategies aimed at managing coffee markets are unlikely to be feasible without consuming country collaboration, given that the government of the United States - which continues to constitute the largest single consuming coffee market - has distanced itself from international institutional cooperation when it left the ICO in 2018 (Brown, 2018). The recent election of a right-wing, pro-market president in Brazil puts such alignment even further out of reach (Arend Laier, 2018).

\subsection{Application of EEG concepts to power dynamics in the coffee GVC}

In addition to supplementing the theoretical framework of Evolutionary Economic Geography with a more multifaceted approach to power, and emphasizing the way in which power played a crucial role in determining value distribution between members of the value chain in each of those steps, we draw on three concepts developed in EEG - path dependence, hysteresis, and punctuated equilibrium - to better understand why power relations have shifted the way they did.

The concept of path dependence draws our attention to the way in which initial conditions of each of the types of power shaped its later outcomes. This is most easily apparent in the case of institutional power, where the early choices regarding the implementation of the ICA - for instance, the assignment of responsibility for allocating country-wide quotas to specific local regulatory systems - created winners and losers. As

the winners who benefitted most were closer to the core institutional structure, and favoured the status quo, it became difficult to reverse early choices in a way to harness institutional power for more marginalized groups. 
The idea of hysteresis, or the independent co-evolution of economic actors and the institutions that constrain them through mutual feedback processes, is visible in the way buyers have aligned their operations with the dominant power structure of each period, while simultaneously influencing the pre-eminence of different ways to maintain control over their value chain. This is particularly visible as we move toward a more differentiated coffee market, where some bargaining power was in danger of moving to producing country actors. This spurred the rapid entry of large companies into the high-quality segment, as well as the reorganization of their supply chains using top-down sourcing management tools. These techniques allowed these companies to amplify their demonstrative power, for instance vis-à-vis the constitutive power of broader consumerand civil society-led movements, by privatizing the definition of quality and sustainability.

Finally, we can find several instances of punctuated equilibria, where the incompatibility of the preeminent power constellations with economic actors' strategy led to a rapid transformation of the institutions at hand. The first, and most obvious, is the dissolution of the International Coffee Agreement in 1989, which had become an increasingly anachronistic example of market control in a trade system dominated by freemarket ideology. Add to that the discontent of several country-level actors over quota distribution, its lack of ability to adapt to changing consumption patterns such as a higher interest in Arabica coffee, and its imperfect enforcement system, it is unsurprising that this supply management system collapsed when it did. After an extended, frantic reorganization of economic actors to weather free-market conditions (another example of hysteresis), we can observe another instance of punctuated equilibrium when Starbucks and other specialty roasters enter the GVC with their proposition of high-value coffee consumption - 
overcoming the stasis of low coffee quality in America which had long frustrated consumers, and usurping leading roasters' demonstrative power to send strong qualityrelated signals to producing countries. A final example of a punctuated equilibrium comes from the roaster reorganization following 2008: in this case, the equilibrium of diversified multinationals with only partial interest in the coffee market became an ever-greater liability during the period of economic downturn. This came to a head during the period of spin-offs and the resulting mergers and acquisition wave that swept the industry and necessitated that the majority of roasters either consolidate or leave the market. The final tally leaves buyers with higher bargaining power over other value chain members than they had for a long time, though the rise in institutional power of producing countries heralds the possibility of a future punctuation of this current equilibrium.

\subsection{Implications for upgrading in the coffee GVC}

Existing research on global value chains, explicitly or implicitly, has analysed governance dynamics mostly by considering bargaining power as the only kind that matters. This analysis shows that a careful consideration of other types of power exercised in GVCs leads to a considerably more nuanced understanding of the distribution of power and value captured between different value chain actors than if we looked at bargaining power alone. More importantly, these insights can contribute to substantially different policy recommendations on how to achieve 'upgrading', or the capture of a greater share of value, which has been a recurring preoccupation in GVC research (Gereffi, 1999a; Fitter and Kaplinsky, 2001; Kaplinsky and Fitter, 2004; Bamber et al., 2014). 
Indeed, if we limited our analysis to the standard GVC categories summarized in Tables 3 and 4, we could find reasons to be optimistic about the potential for greater value share capture in the coffee GVC across by actors in producing countries. Particularly in relation to specialty coffee, an increasing number of producing-country actors have moved into the differentiation and upgrading pathways that are generally recommended in the GVC literature (Gereffi 1999a; Kaplinsky and Fitter 2004). From a traditional GVC perspective, the move toward single-origin provenance decouples high-quality coffee from the mainstream, fungible commodity market, and allows greater bargaining power to be in the hands of producers; and the rise of direct trade and relationship coffees could contribute to lower transaction costs (due to fewer middlemen), greater transparency in along the value chain, and the establishment of longer-term, more equitable terms of trade.

Yet, if we consider other types of power dynamics, a different picture emerges. Institutional power, despite massive liberalization in domestic markets in producing countries, is still playing a role - albeit a much weaker one than during the ICA period. Demonstrative and constitutional forms of power play very important roles in the highquality segment, and flow unidirectionally from the North to the South - casting doubts on whether specialization in differentiated coffees allows for sustained shifts in the sociospatial distribution of value and risk. In sum, we find new dependency relationships emerging, which are closely linked to Northern-dominated definitions of quality. Thus, we observe shifts in the type of power, not in its locus or its geographical distribution, through these upgrading pathways. 


\section{Conclusion}

Through an evolutionary approach to power dynamics, this article has examined the multifacetedness of governance structures in global value chains, and how dominant actors exert, navigate or opportunistically leverage various combinations of power in different periods to generate and capture value. The article showcases the co-evolution of both market actor arrangements and surrounding institutions in three distinct phases of governance in the coffee GVC: between the first phase and the second phase, the institutional environment changed, with market actors adapting their strategies and relationships accordingly; between the second phase and the third phase, change was driven mainly by the reorganization efforts of lead firms, with public institutions attempting to mitigate bargaining power inequalities by strengthening both unilateral as well as multilateral efforts to safeguard producer incomes.

We conclude that although recent changes in the coffee GVC toward a more heterogenous and stratified product portfolio may lend constitutive power to producing country actors, particularly when proposing new specialty coffees, the overwhelming tendency in current re-consolidation efforts is one where large disparities in both bargaining and demonstrative power persist - translating into buyers being able to impose increasingly stringent terms onto their suppliers. The simultaneous but partial renaissance of producing-country institutional power, through unilateral and incipient multilateral means (e.g. the World Coffee Producers' Forum), constitutes an important effort for addressing unequal exchange. However, as the experience of the International Coffee Agreement has shown, such efforts frequently face collective action, free-rider, and rentseeking problems. It is thus important for future research to critically evaluate the ability 
of re-emerging institutional power, vis-à-vis other kinds of power, to improve on-theground production realities for small-scale producers.

More broadly, the specific power and governance dynamics that characterize individual value chains can provide important and fine-tuned pointers for public authorities and social movements on how various actions applying demonstrative, institutional and/or constitutional power can be used to undermine unequal bargaining positions. A future research agenda in this field will need to build upon recent analytical innovations in GVC governance and the GPN 2.0 framework, but will also need to extend them through a nuanced handling of power dynamics. This may further be complemented by an analysis of power relations within the wider institutional and social setting that global value chains are embedded in.

Our evolutionary analysis furthermore underscores that dominant market actors strategically and flexibly move into niche sectors with high value addition potential and reimpose structural value chain conditions to (re)capture value from producers through the hysteresis of power relations. Taking into account the contingent spatio-temporality of value capture trajectories, our results thus caution against an over-reliance on market-based solutions for improving the equity of production outcomes in GVCs and suggest that domestic institutions can still play an important role in supporting (especially smallholder) producers. Using the lens of evolutionary economic geography further alerts us to the importance of appreciating opportune moments to change power relations (when punctuated equilibria are likely to occur), and pay high attention to the initial conditions of new institutional set-ups, given the likelihood of path-dependent developments that will make revisiting distributional arrangements more difficult in due time. 
We thus encourage future work to expand on using evolutionary economic geography approaches to the analysis of power relations in global value chains. As this article has shown, applying an evolutionary perspective not only allows us to look back at changing supply chain conditions in a theoretically robust fashion, but also to anticipate the outcomes of future instances of value chain re-organization and their consequences for the development and value capture of marginalized producers. This perspective might therefore also be useful for forward-looking policy advice on how to create strong and equitable global value chains.

\section{References}

Adams, W.L., Love, H.A., Capps, O. (1997) Structural Analysis Of Mergers And Acquisitions In The Food Industry. Journal of Food Distribution Research, 28(2): 1-13.

Adelaja, A., Nayga, R., Farooq, Z. (1999) Predicting mergers and acquisitions in the food industry. Agribusiness, 15(1):1-23. doi: https://doi.org/10.1002/(SICI)15206297(199924)15:1<1::AID-AGR1>3.0.CO;2-N.

Arend Laier, P. (2018) Brazil Markets Cheered by Pro-Business Make-Up of Bolsonaro Team. Reuters, 16 November, available at https://www.reuters.com/article/us-brazilpolitics-idUSKCN1NL2DP (Accessed: 15 January 2019).

Armstrong, A. (2014) Mondelez and Douwe Egberts Maker in Coffee Mega-Merger. Telegraph, 7 May, available at http://www.telegraph.co.uk/finance/newsbysector/retailandconsumer/10814141/Mondele z-and-Douwe-Egberts-maker-in-coffee-mega-merger.html (Accessed: 7 November 2016).

Bachrach, P., Baratz, M.S. (1962) Two Faces of Power. The American Political Science Review, 56(4): 947-952. doi: https://doi.org/10.2307/1952796.

Bair, J., Palpacuer, F. (2015) CSR Beyond the Corporation: Contested Governance in Global Value Chains. Global Networks, 15(s1): S1-S19. doi:

https://doi.org/10.1111/glob.12085.

Bamber, P., Guinn, A., Gereffi, G. (2014) Burundi in the Coffee Global Value. Center on Globalization, Governance \& Competitiveness, Duke University. 
Bates, R. (1999) Open-Economy Politics: The Political Economy of the World Coffee Trade. Princeton, N.J.: Princeton University Press.

Bitzer, V., Francken, M., Glasbergen, P. (2008) Intersectoral Partnerships for a Sustainable Coffee Chain: Really Addressing Sustainability or Just Picking (Coffee) Cherries? Global Environmental Change, 18(2): 271-284. doi:

https://doi.org/10.1016/j.gloenvcha.2008.01.002.

Bloomberg News (2016) Food industry hungry for mergers and profitable buys. The Denver Post, 10 July, available at http://www.denverpost.com/2016/07/10/food-industryhungry-for-mergers-and-profitable-buys/ (Accessed: 7 November 2017).

Boschma, R., Frenken, K. (2006). Why is Economic Geography not an Evolutionary Science? Towards an Evolutionary Economic Geography. Journal of Economic Geography, 6(3): 273-302. doi: https://doi.org/10.1093/jeg/lbi022.

Boschma, R., Frenken, K. (2009) Some Notes on Institutions in Evolutionary Economic Geography. Economic Geography, 85(2): 151-158. doi: https://doi.org/10.1111/j.19448287.2009.01018.x.

Boschma, R., Frenken, K. (2011) The Emerging Empirics of Evolutionary Economic Geography. Journal of Economic Geography, 11(2): 295-307. doi: https://doi.org/10.1093/jeg/lbq053.

Boschma, R., Martin, R. (2007) Editorial: Constructing an Evolutionary Economic Geography. Journal of Economic Geography, 7(5): 537-548. doi:

https://doi.org/10.1093/jeg/lbm021.

Brown, N. (2018) The United States is withdrawing from the International Coffee Agreement. Daily Coffee News by Roast Magazine, 03 April, available at https://dailycoffeenews.com/2018/04/03/the-united-states-is-withdrawing-from-theinternational-coffee-agreement/ (Accessed: 09 May 2018).

Clapp, J., Fuchs, D. (eds.) (2009) Corporate Power in Global Agrifood Governance. 1 edition. Cambridge, Mass: The MIT Press.

Coe, N.M., Dicken, P., Hess, M. (2008) Global Production Networks: Realizing the Potential. Journal of Economic Geography, 8(3): 271-295. doi:

https://doi.org/10.1093/jeg/lbn002.

Coe, N.M., Hess, M., Yeung, H.W. -C., Dicken, P., Henderson, J. (2004) 'Globalizing' Regional Development: A Global Production Networks Perspective. Transactions of the Institute of British Geographers, 29(4): 468-484. doi: https://doi.org/10.1111/j.00202754.2004.00142.x.

Coe, N.M., Yeung, H.W. -C. (2015) Global Production Networks: Theorizing Economic Development in an Interconnected World. Oxford: Oxford University Press. 
Cohen, L. (2015) Exclusive: Keurig Deal Gives Coffee Traders Jitters about Payments. Reuters, 09 December, available at http://www.reuters.com/article/us-keurig-green-m-acoffee-exclusive-idUSKBNOTSOFW20151209 (Accessed: 28 October 2016).

Dahl, R.A. (1957) The Concept of Power. Behavioral Science, 2(3): 201-215. doi: https://doi.org/10.1002/bs.3830020303.

Dallas, M., Ponte, S., Sturgeon, T. (2017) A Typology of Power in Global Value Chains. Working Paper in Business and Politics 92, Copenhagen Business School.

Daviron, B., Ponte, S. (2005) The Coffee Paradox: Global Markets, Commodity Trade and the Elusive Promise of Development. London; New York: Zed Books.

Digeser, P. (1992) The Fourth Face of Power. The Journal of Politics, 54(4): 977-1007. doi: https://doi.org/10.2307/2132105.

Elder, S.D., Lister, J., Dauvergne, P. (2014) Big Retail and Sustainable Coffee: A New Development Studies Research Agenda. Progress in Development Studies, 1: 77-90.

Fitter, R., Kaplinsky, R. (2001) Who Gains from Product Rents as the Coffee Market Becomes More Differentiated? A Value Chain Analysis. IDS Bulletin, 32(3): 69-82.

Gallie, W.B. (1956) Essentially Contested Concepts. Proceedings of the Aristotelian Society, 56: 167-198.

Gara, A. (2015) Why The World's Smartest Investors Are Betting On Burgers, Beer, Coffee And Condoms. Forbes, 07 December, available at https://www.forbes.com/sites/antoinegara/2015/12/07/why-the-worlds-smartestinvestors-are-betting-on-burgers-beer-coffee-and-condoms/ (Accessed: 15 January 2019).

Gasparro, A. (2015) Keurig Green Mountain Taken Private in \$13.9 Billion Deal. Wall Street Journal, 08 December, available at http://www.wsj.com/articles/keurig-greenmountain-agrees-to-get-bought-for-13-9-billion-1449493939 (Accessed: 07 November 2016).

Gereffi, G. (1994) The Organization of Buyer-Driven Global Commodity Chains: How U.S. Retailers Shape Overseas Production Networks. In: Gereffi, G., Korzeniewicz, M. (eds.) Commodity Chains and Global Capitalism. Westport: Greenwood Press.

Gereffi, G. (1999a) International Trade and Industrial Upgrading in the Apparel Commodity Chain. Journal of International Economics, 48(1): 37-70. doi: https://doi.org/10.1016/S0022-1996(98)00075-0.

Gereffi, G. (1999b) A Commodity Chains Framework for Analyzing Global Industries. Institute of Development Studies: 8(12): 1-9. 
Gereffi, G., Humphrey, J., Sturgeon, T. (2005) The Governance of Global Value Chains. Review of International Political Economy, 12(1): 78-104. doi:

https://doi.org/10.1080/09692290500049805.

Gibbon, P., Bair, J., Ponte, S. (2008) Governing Global Value Chains: An Introduction. Economy and Society, 37(3): 315-338. doi:

https://doi.org/info:doi/10.1080/03085140802172656.

Gibbon, P., Ponte, S. (2005) Trading down: Africa, Value Chains, and the Global Economy. Philadelphia: Temple University Press.

Gibbon, P., Ponte, S. (2008) Global Value Chains: From Governance to Governmentality? Economy and Society, 37(3): 365-392. doi:

https://doi.org/10.1080/03085140802172680.

Glückler, J., Panitz, R. (2016) Relational Upgrading in Global Value Networks. Journal of Economic Geography, 16(6): 1161-1185. doi: https://doi.org/10.1093/jeg/lbw033.

Gold, J. (2008) La Mill: The Latest Buzz. LA Weekly, 12 March, available at http://www.laweekly.com/restaurants/la-mill-the-latest-buzz-2152451 (Accessed: 26 June 2018).

Grabs, J. (2017). The Rise of Buyer-Driven Sustainability Governance: Emerging Trends in the Global Coffee Sector. ZenTra Working Paper in Transnational Studies No. 73.

Rochester, NY: Social Science Research Network.

Grabs, J. (2018) Assessing the Institutionalization of Private Sustainability Governance in a Changing Coffee Sector. Regulation \& Governance early view. doi:

https://doi.org/10.1111/rego.12212.

Gretler, C. (2015) Nestle to Lose Single-serve Coffee Crown as JAB Snags Keurig.

Bloomberg.com, 08 December, available at

http://www.bloomberg.com/news/articles/2015-12-08/nestle-to-lose-single-serve-coffeecrown-as-reimanns-snag-keurig (Accessed: 22 November 2016).

Grugel, J., Riggirozzi, P. (2012) Post-neoliberalism in Latin America: Rebuilding and Reclaiming the State after Crisis. Development and Change, 43(1): 1-21. doi: https://doi.org/10.1111/j.1467-7660.2011.01746.x.

Hassink, R., Klaerding, C., Marques, P. (2014) Advancing Evolutionary Economic Geography by Engaged Pluralism. Regional Studies, 48(7): 1295-1307. doi: https://doi.org/10.1080/00343404.2014.889815.

Henderson, J., Dicken, P., Hess, M., Coe, N., Yeung, H.W.-C. (2002) Global Production Networks and the Analysis of Economic Development. Review of International Political Economy, 9(3): 436-464. doi: https://doi.org/10.1080/09692290210150842. 
Hess, M. and Yeung, H.W.-C. (2006) Whither Global Production Networks in Economic Geography? Past, Present, and Future. Environment and Planning A: Economy and Space, 38(7): 1193-1204. doi: https://doi.org/10.1068/a38463.

Jespersen, K.S., Kelling, I., Ponte, S., Kruijssen, F. (2014) What Shapes Food Value Chains? Lessons from Aquaculture in Asia. Food Policy, 49: 228-240. doi: https://doi.org/10.1016/j.foodpol.2014.08.004.

Jones, A. (2008) Beyond Embeddedness: Economic Practices and the Invisible Dimensions of Transnational Business Activity. Progress in Human Geography, 32(1): 71-88. doi: https://doi.org/10.1177/0309132507084817.

Kaplinsky, R., Fitter, R. (2004) Technology and Globalisation: Who Gains When Commodities Are De-Commodified? International Journal of Technology \& Globalisation, 1(1): 5-28.

Key, D. (2015) JAB to Challenge Nestle, Global Leader of Portioned Coffee Market. Market Realist, 12 November, available at http://marketrealist.com/2015/12/jabchallenge-nestle-global-leader-portioned-coffee-market/ (Accessed: 27 October 2016).

Landini, F., Clarke, D. (2016) Lavazza to Seal 750 Mln Euro Carte Noire Buy this Month -Sources. Reuters, 01 February, available at http://www.reuters.com/article/cartenoirema-lavazza-idUSI6N15302N (Accessed: 27 October 2016).

Levy, D., Reinecke, J., Manning, S. (2016) The Political Dynamics of Sustainable Coffee: Contested Value Regimes and the Transformation of Sustainability. Journal of Management Studies, 53(3): 364-401.

Levy, D.L. (2008) Political Contestation in Global Production Networks. Academy of Management Review, 33(4): 943-963. doi: https://doi.org/10.5465/AMR.2008.34422006.

Lora, E. (2013) Las Políticas y las Instituciones Cafeteras alrededor del Mundo. Misión de Estudios Para La Competitividad de La Caficultura En Colombia. Bogota.

Lukes, S. (1974) Power: A Radical View. London: Macmillan.

Luttinger, N., Dicum, G. (2011) The Coffee Book: Anatomy of an Industry from Crop to the Last Drop. New York: The New Press.

MacGregor, F., Ramasar, V., Nicholas, K.A. (2017) Problems with Firm-Led Voluntary Sustainability Schemes: The Case of Direct Trade Coffee. Sustainability, 9(4): 651. doi: https://doi.org/10.3390/su9040651.

MacKinnon, D. (2012) Beyond Strategic Coupling: Reassessing the Firm-Region Nexus in Global Production Networks. Journal of Economic Geography, 12(1): 227-245. doi: https://doi.org/10.1093/jeg/lbr009. 
MacKinnon, D., Cumbers, A., Pike, A., Birch, K., McMaster, R. (2009) Evolution in Economic Geography: Institutions, Political Economy, and Adaptation. Economic Geography, 85(2): 129-150. doi: https://doi.org/10.1111/j.1944-8287.2009.01017.x.

Martin, R., Sunley, P. (2006) Path Dependence and Regional Economic Evolution. Journal of Economic Geography, 6(4): 395-437. doi: https://doi.org/10.1093/jeg/lbl012.

Milberg, W., Winkler, D. (2013) Outsourcing Economics: Global Value Chains in Capitalist Development. Cambridge; New York: Cambridge University Press.

Muehlfeld, K., Weitzel, U., van Witteloostuijn, A. (2011) Mergers and acquisitions in the global food processing industry in 1986-2006. Food Policy 36(4): 466-479. doi: https://doi.org/10.1016/j.foodpol.2011.05.002.

Muradian, R., Pelupessy, W. (2005) Governing the Coffee Chain: The Role of Voluntary Regulatory Systems. World Development, 33(12): 2029-2044. doi:

https://doi.org/10.1016/j.worlddev.2005.06.007.

Nadvi, K. (2008) Global Standards, Global Governance and the Organization of Global Value Chains. Journal of Economic Geography, 8(3): 323-343. doi:

https://doi.org/10.1093/jeg/lbn003.

Neilson, J., Pritchard, B. (2009) Value Chain Struggles: Institutions and Governance in the Plantation Districts of South India. Chichester, U.K.; Malden, MA: Wiley-Blackwell.

Newman, S. (2009) Financialization and Changes in the Social Relations along Commodity Chains: The Case of Coffee. Review of Radical Political Economics, 41(4): 539-559. doi: https://doi.org/10.1177/0486613409341454.

Oro, K., Pritchard, B. (2011) The Evolution of Global Value Chains: Displacement of Captive Upstream Investment in the Australia-Japan Beef Trade. Journal of Economic Geography, 11(4): 709-729. doi: https://doi.org/10.1093/jeg/lbq008.

Ouma, S. (2010) Global Standards, Local Realities: Private Agrifood Governance and the Restructuring of the Kenyan Horticulture Industry. Economic Geography, 86(2): 197222. doi: https://doi.org/10.1111/j.1944-8287.2009.01065.x.

Ouma, S. (2015) Assembling Export Markets: The Making and Unmaking of Global Food Connections in West Africa. Chichester, West Sussex, UK; Malden, MA: WileyBlackwell.

Pendergrast, M. (2010) Uncommon Grounds: The History of Coffee and How It Transformed Our World. New York: Basic Books.

Pike, A., Birch, K., Cumbers, A., MacKinnon, D., McMaster, R. (2009). A Geographical Political Economy of Evolution in Economic Geography. Economic Geography, 85(2): 175-182. doi: https://doi.org/10.1111/j.1944-8287.2009.01021.x. 
Ponte, S. (2002) The 'Latte Revolution'? Regulation, Markets and Consumption in the Global Coffee Chain. World Development, 30(7): 1099-1122. doi:

https://doi.org/10.1016/S0305-750X(02)00032-3.

Ponte, S. (2019) Green Capital, Brown Environments: Business, Power and

Sustainability in a World of Global Value Chains. London and New York: Zed Books.

Ponte, S., Ewert, J. (2009) Which Way is "Up" in Upgrading? Trajectories of Change in the Value Chain for South African Wine. World Development, 37(10): 1637-1650. doi: https://doi.org/10.1016/j.worlddev.2009.03.008.

Ponte, S., Gibbon, P. (2005) Quality Standards, Conventions and the Governance of Global Value Chains. Economy and Society, 34(1): 1-31. doi:

https://doi.org/10.1080/0308514042000329315.

Ponte, S., Sturgeon, T. (2014) Explaining Governance in Global Value Chains: A Modular Theory-Building Effort. Review of International Political Economy, 21:195223. doi: https://doi.org/10.1080/09692290.2013.809596.

Raj-Reichert, G. (2013) Safeguarding Labour in Distant Factories: Health and Safety Governance in an Electronics Global Production Network. Geoforum, 44: 23-31. doi: https://doi.org/10.1016/j.geoforum.2012.05.007.

Rossi, A. (2013) Does Economic Upgrading Lead to Social Upgrading in Global Production Networks? Evidence from Morocco. World Development, 46: 223-233. doi: https://doi.org/10.1016/j.worlddev.2013.02.002.

Selwyn, B. (2012) Beyond Firm-Centrism: Re-integrating Labour and Capitalism into Global Commodity Chain Analysis. Journal of Economic Geography, 12(1): 205-226. doi: https://doi.org/10.1093/jeg/lbr016.

Selwyn, B. (2015) Commodity Chains, Creative Destruction and Global Inequality: A Class Analysis. Journal of Economic Geography, 15(2): 253-274. doi:

https://doi.org/10.1093/jeg/lbu014.

Smith, A., Pickles, J., Buček, M., Pástor, R., Begg, B. (2014) The Political Economy of Global Production Networks: Regional Industrial Change and Differential Upgrading in the East European Clothing Industry. Journal of Economic Geography, 14(6): 10231051. doi: https://doi.org/10.1093/jeg/lbt039.

Statista (2016) Coffee Retail Market Share Worldwide in 2014, Statista, available at https://www.statista.com/statistics/323254/global-retail-coffee-market-share-bycompany/ (Accessed: 27 October 2016).

Talbot, J.M. (1997) Where does your Coffee Dollar Go?: The Division of Income and Surplus along the Coffee Commodity Chain. Studies in Comparative International Development, 32(1): 56-91. doi: https://doi.org/10.1007/BF02696306. 
Talbot, J.M. (2004) Grounds for Agreement: The Political Economy of the Coffee Commodity Chain. Rowman \& Littlefield Publishers.

Tokatli, N. (2013) Toward a Better Understanding of the Apparel Industry: A Critique of the Upgrading Literature. Journal of Economic Geography, 13(6): 993-1011. doi: https://doi.org/10.1093/jeg/lbs043.

Trefis Team (2014a). The Year 2014 In Review: Keurig Green Mountain. Forbes, 31 December, available at http://www.forbes.com/sites/greatspeculations/2014/12/31/theyear-2014-in-review-keurig-green-mountain/ (Accessed: 7 November 2016).

Trefis Team (2014b). Starbucks' Top-Line Growth in FY2014 Driven By Higher Pricing \& Accelerated Expansion In New Beverage Segments. Forbes, 31 October, available at http://www.forbes.com/sites/greatspeculations/2014/10/31/starbucks-top-line-growth-infy2014-driven-by-higher-pricing-accelerated-expansion-in-new-beverage-segments/ (Accessed: 7 November 2016).

Vicol, M., Neilson, J., Hartatri, D.F.S., Cooper, P. (2018) Upgrading for Whom? Relationship Coffee, Value Chain Interventions and Rural Development in Indonesia. World Development, 110: 26-37. doi: https://doi.org/10.1016/j.worlddev.2018.05.020.

Watson, J. (2017) Coffee Consolidation Accelerates. Rabobank RaboResearch, July, available at https://research.rabobank.com/far/en/sectors/beverages/Coffee_Consolidation_Accelerate s.html (Accessed: 30 May 2018).

Werner, M. (2012) Beyond Upgrading: Gendered Labor and the Restructuring of Firms in the Dominican Republic. Economic Geography, 88(4): 403-422. doi:

https://doi.org/10.1111/j.1944-8287.2012.01163.x.

Wilson, A.P., Wilson, N.L.W. (2014) The Economics of Quality in the Specialty Coffee Industry: Insights from the Cup of Excellence Auction Programs. Agricultural Economics, 45: 91-105. doi: https://doi.org/10.1111/agec.12132.

Yates, J.S., Bakker, K. (2014) Debating the 'Post-Neoliberal Turn' in Latin America. Progress in Human Geography, 38(1): 62-90. doi:

https://doi.org/10.1177/0309132513500372.

Yeung, H.W.-C. (2009) Regional Development and the Competitive Dynamics of Global Production Networks: An East Asian Perspective. Regional Studies, 43(3): 325-351. doi: https://doi.org/10.1080/00343400902777059.

Yeung, H.W.-C. and Coe, N. (2015) Toward a Dynamic Theory of Global Production Networks. Economic Geography, 91(1): 29-58. doi: https://doi.org/10.1111/ecge.12063. 


\section{Tables and figures}

Table 1. A typology of power in GVCs. Source: adapted from Dallas, Ponte and Sturgeon (2017)

\begin{tabular}{|l|c|c|}
\hline $\begin{array}{l}\text { Dyadic actor } \\
\text { constellation }\end{array}$ & $\begin{array}{c}\text { Direct transmission } \\
\text { (operates in firm-to-firm } \\
\text { relations with various degrees } \\
\text { of asymmetry) }\end{array}$ & $\begin{array}{c}\text { Diffuse transmission } \\
\text { (operates through informal transmission } \\
\text { mechanisms along value chains) }\end{array}$ \\
\hline $\begin{array}{l}\text { Collective actor } \\
\text { constellation }\end{array}$ & $\begin{array}{c}\text { Institutional power } \\
\text { (operates through government } \\
\text { regulation, multi-stakeholder } \\
\text { initiatives or other } \\
\text { institutionalized forms) }\end{array}$ & $\begin{array}{c}\text { Constitutive power } \\
\text { (operates through broadly accepted or } \\
\text { taken for granted norms, conventions } \\
\text { and best practices; includes isomorphist } \\
\text { dynamics and 'structural power') }\end{array}$ \\
\hline
\end{tabular}

Table 2. Overview of recent expert interviews

\begin{tabular}{ccccccc}
\hline $\begin{array}{c}\text { Interviewee } \\
\text { type }\end{array}$ & Roasters & Traders & $\begin{array}{c}\text { Producer } \\
\text { organizations }\end{array}$ & Institutions & NGOs & $\begin{array}{c}\text { Fellow } \\
\text { researchers }\end{array}$ \\
\hline Interviews & 15 & 17 & 10 & 8 & 9 & 6 \\
\hline
\end{tabular}




\begin{tabular}{|c|c|c|c|}
\hline GVC features & ICA regime phase (1962-1989) & Liberalization phase (1989-2007) & $\begin{array}{l}\text { Diversification and reconsolidation phase (2008- } \\
\text { present) }\end{array}$ \\
\hline $\begin{array}{l}\text { Geography of } \\
\text { production }\end{array}$ & $\begin{array}{l}\text { At first concentrated in few large producing } \\
\text { countries (Brazil, Colombia); later, } \\
\text { increasingly dispersed with the emergence of } \\
\text { new producers }\end{array}$ & Fragmentation continues & $\begin{array}{l}\text { Re-concentration as productivity and cost advantages of } \\
\text { large producers (Brazil, Vietnam, Colombia, but also } \\
\text { Honduras) leads to decrease in coffee areas in marginal } \\
\text { countries }\end{array}$ \\
\hline $\begin{array}{l}\text { Entry barriers to } \\
\text { production }\end{array}$ & $\begin{array}{l}\text { Low, due to government intervention (input } \\
\text { and credit supply, extension, coffee } \\
\text { cultivation campaigns, price stabilization) }\end{array}$ & $\begin{array}{l}\text { Increased, due to government withdrawal from } \\
\text { the provision of services to farmers (end of input } \\
\text { supply schemes, breakdown of research and } \\
\text { extension networks, end of price stabilization } \\
\text { mechanisms) }\end{array}$ & $\begin{array}{l}\text { Stay high due to low median prices, increasing input } \\
\text { costs and labour shortages, climate-change related pest } \\
\text { and disease outbreaks such as coffee rust, generational } \\
\text { change; in some cases, slightly lower due to government } \\
\text { or project support }\end{array}$ \\
\hline $\begin{array}{l}\text { Characteristics } \\
\text { of } \\
\text { internationally } \\
\text { traded product }\end{array}$ & $\begin{array}{l}\text { Relatively homogeneous, but distinguished } \\
\text { by physical and intrinsic qualities (the latter } \\
\text { especially for Mild Arabica) }\end{array}$ & $\begin{array}{l}\text { Bifurcated trend: increased homogenization of } \\
\text { lower quality coffees, especially Robusta (bulk } \\
\text { export in containers without bags); at the same } \\
\text { time, increased trade of small quantities of } \\
\text { specific high-end-quality beans (Mild Arabica) }\end{array}$ & $\begin{array}{l}\text { Continued dominance in volume of non-differentiated } \\
\text { lower-quality Arabica and Robusta; improvements in } \\
\text { traceability technology leads to increased differentiation } \\
\text { in regional, quality, varietal and sustainability attributes } \\
\text { of high-quality coffee in Arabicas and first attempts to } \\
\text { differentiate high-quality Robustas }\end{array}$ \\
\hline $\begin{array}{l}\text { Entry barriers to } \\
\text { trade }\end{array}$ & $\begin{array}{l}\text { Domestic trade and export: high barriers due } \\
\text { to monopoly of marketing or politically set } \\
\text { domestic trade quotas } \\
\begin{array}{l}\text { International trade: increasing due to } \\
\text { consolidation }\end{array}\end{array}$ & $\begin{array}{l}\text { Domestic trade and export: first, decreased entry } \\
\text { barriers due to liberalization; later, increased } \\
\text { barriers following the strengthening of } \\
\text { international trader operations in producing } \\
\text { countries } \\
\text { International trade: increasing entry barriers in } \\
\text { 'fair-average-quality' market due to further } \\
\text { consolidation and requirements set by roasters } \\
\text { through SMI; decreasing in the specialty market } \\
\text { due to fragmentation and the growing importance } \\
\text { of e-commerce sales }\end{array}$ & $\begin{array}{l}\text { Domestic trade and export: increased barriers due to price } \\
\text { volatility and increased financialization of the sector; } \\
\text { dominance in price-setting and storage capacity of } \\
\text { international actors; in some countries bureaucratic } \\
\text { hurdles for export } \\
\text { International trade: Increased barriers consists of } \\
\text { sustainability certification expectation with little to no } \\
\text { price premium; entry requirement to specialty market } \\
\text { governed by increasingly stringent cupping score cut-offs } \\
\text { that are only discovered ex-post }\end{array}$ \\
\hline $\begin{array}{l}\text { Distribution of } \\
\text { income } \\
\text { generated along } \\
\text { the chain }\end{array}$ & $\begin{array}{l}\text { Relatively stable, with farmers getting around } \\
20 \% \text { of the total, and consuming country } \\
\text { operators around } 50 \%\end{array}$ & $\begin{array}{l}\text { Shifted to the advantage of consuming country } \\
\text { operators }\end{array}$ & $\begin{array}{l}\text { Continues to the advantage of consuming countries; } \\
\text { increasing transparency of distribution in specialty coffee } \\
\text { supply chains }\end{array}$ \\
\hline $\begin{array}{l}\text { Geography of } \\
\text { consumption }\end{array}$ & $\begin{array}{l}\text { Concentrated in North America, Western } \\
\text { Europe and Japan }\end{array}$ & $\begin{array}{l}\text { Emergence of new markets (Eastern Europe, } \\
\text { China, East Asia) }\end{array}$ & $\begin{array}{l}\text { Saturation of traditional markets except for growth in } \\
\text { value of specialty market (linked to generational change); } \\
\text { growth of new markets, also in producing countries } \\
\text { (Brazil, Colombia) }\end{array}$ \\
\hline
\end{tabular}




\begin{tabular}{|c|c|c|c|}
\hline $\begin{array}{l}\text { Typology of } \\
\text { consumption }\end{array}$ & $\begin{array}{l}\text { Segmented by group of countries (different } \\
\text { coffee types and blends catering for the } \\
\text { USA/UK markets, Southern Europe, } \\
\text { Scandinavia, Central Europe, Japan), but } \\
\text { relatively homogeneous consumption within } \\
\text { these geographical areas }\end{array}$ & $\begin{array}{l}\text { Increased fragmentation: multiplication of types } \\
\text { of product and blurring of distinctive lines of } \\
\text { preference between different groups of countries; } \\
\text { increasing importance of single origin coffees }\end{array}$ & $\begin{array}{l}\text { Globalization; income- and generation-based } \\
\text { crystallization of types of consumption that are similar } \\
\text { across countries: instant coffee (emerging economies, } \\
\text { low-income segment); ground coffee (lower middle } \\
\text { class, Baby Boomers); single-serve capsules (upper } \\
\text { middle class, Gen X); specialty, milk-based and single- } \\
\text { origin coffees (upper middle class, Gen Y and } \\
\text { millennials) }\end{array}$ \\
\hline
\end{tabular}

Table 3. Coffee GVC restructuring (input-output framework and geographical distribution). Source: modified and updated from Ponte (2002)

Table 4. Coffee GVC restructuring (governance structure, institutional framework and upgrading). Source: modified and updated from Ponte (2002)

\begin{tabular}{|c|c|c|c|}
\hline GVC features & ICA regime phase (1962-1989) & Liberalization phase (1989-2007) & $\begin{array}{l}\text { Diversification and reconsolidation phase (2008- } \\
\text { present) }\end{array}$ \\
\hline $\begin{array}{l}\text { Governance } \\
\text { structure of the } \\
\text { chain }\end{array}$ & $\begin{array}{l}\text { Low level of 'drivenness'; increasing } \\
\text { concentration in roasting and trading } \\
\text { segments raises entry barriers, but roasters } \\
\text { are neither in the position to dictate the terms } \\
\text { of the trade to traders, nor to set } \\
\text { inclusion/exclusion thresholds; control over } \\
\text { the chain by any actor is limited }\end{array}$ & $\begin{array}{l}\text { 'Buyer-driven' (specifically, roaster-driven); } \\
\text { further consolidation in roasting; oversupply; } \\
\text { adoption of SMI by roasters forces traders to } \\
\text { integrate upstream; vertical integration by traders } \\
\text { made easier by market liberalization in } \\
\text { producing countries }\end{array}$ & $\begin{array}{l}\text { Still 'buyer-driven' (with roasters as strongest actors, in } \\
\text { some cases also retailers); re-consolidation of roasters } \\
\text { after period of diversification in different subsectors; } \\
\text { more stringent financing terms for traders; top-down } \\
\text { determined choice of sustainability standards; growing } \\
\text { influence of small specialty roasters that focus mainly on } \\
\text { quality }\end{array}$ \\
\hline $\begin{array}{l}\text { Vertical } \\
\text { integration }\end{array}$ & $\begin{array}{l}\text { Not common; sometimes occurring in } \\
\text { export/international trade links; more rarely } \\
\text { into domestic trade and processing }\end{array}$ & $\begin{array}{l}\text { Increasing; international traders integrate into } \\
\text { export, processing, domestic trade and } \\
\text { sometimes even estate production; vertical } \\
\text { integration much more limited in the roaster- } \\
\text { international trader link }\end{array}$ & $\begin{array}{l}\text { International traders' integration expands - from farms } \\
\text { to processing to shipping and handling; examples of } \\
\text { roasters entering in direct coffee production (Starbucks); } \\
\text { emergence of direct trade value chains with few } \\
\text { middlemen }\end{array}$ \\
\hline $\begin{array}{l}\text { Producer- } \\
\text { consumer } \\
\text { country } \\
\text { relations }\end{array}$ & $\begin{array}{l}\text { In relative equilibrium; mediated through the } \\
\text { ICAs }\end{array}$ & $\begin{array}{l}\text { Absence of formalized relations; consuming } \\
\text { country domination }\end{array}$ & $\begin{array}{l}\text { Successful individual cases of cooperation through } \\
\text { development financing, public private partnerships and } \\
\text { private roasters' engagement; no formalized relations } \\
\text { beyond the ICO }\end{array}$ \\
\hline $\begin{array}{l}\text { Institutional } \\
\text { framework }\end{array}$ & Strong: international trade regulated by ICAs & $\begin{array}{l}\text { Weak: end of ICA; producing country cartels fail } \\
\text { to set up effective quota or retention schemes; }\end{array}$ & $\begin{array}{l}\text { Weak: ICO maintains a purely advisory function; no } \\
\text { quota schemes re-emerge; price volatility increases; anti- }\end{array}$ \\
\hline
\end{tabular}




\begin{tabular}{|c|c|c|c|}
\hline (international) & & $\begin{array}{l}\text { futures market increasingly de-linked from } \\
\text { market fundamentals }\end{array}$ & $\begin{array}{l}\text { trust institutions do not object to mergers; however, new } \\
\text { voluntary industry platforms emerge }\end{array}$ \\
\hline $\begin{array}{l}\text { Institutional } \\
\text { framework } \\
\text { (domestic) }\end{array}$ & $\begin{array}{l}\text { Strong: markets monopolized by marketing } \\
\text { boards, or regulated by stabilization funds } \\
\text { and quasi-governmental producer } \\
\text { associations }\end{array}$ & $\begin{array}{l}\text { Weak: government and quasi-government } \\
\text { institutions retreat into oversight functions or are } \\
\text { eliminated altogether; trade associations fill only } \\
\text { part of the formal institutional vacuum }\end{array}$ & $\begin{array}{l}\text { Mixed: Most governments and quasi-government } \\
\text { institutions remain underfunded and have limited } \\
\text { responsibilities; others reinvent themselves as strong } \\
\text { marketing and quality control institutions and act as } \\
\text { partners of international value chain actors }\end{array}$ \\
\hline $\begin{array}{l}\text { Quality } \\
\text { conventions }\end{array}$ & $\begin{array}{l}\text { International-level: product-based; set in } \\
\text { negotiation with producing-country sellers } \\
\text { (and/or marketing boards) and maintained via } \\
\text { instrument-based testing and inspection, cup } \\
\text { testing, and certification of the product; in } \\
\text { general, quality assessed by the buyer ex-post } \\
\text { Domestic-level: set by a regulatory agency; } \\
\text { includes specific quality control procedures } \\
\text { along the chain }\end{array}$ & $\begin{array}{l}\text { International-level: increasing importance of } \\
\text { conventions defined by buyers; process } \\
\text { monitoring (in addition to product testing) } \\
\text { becomes important for fair trade, organic, shade- } \\
\text { grown coffees; quality increasingly assessed by } \\
\text { buyers ex-ante } \\
\text { Domestic-level: increasingly set by buyers; } \\
\text { formal rules of quality control remain but are } \\
\text { increasingly disregarded }\end{array}$ & $\begin{array}{l}\text { International-level: spread of Q-grading cupping } \\
\text { methodology to producer level; common language also } \\
\text { through 'flavour wheel' education; process monitoring } \\
\text { (certifications) grows in complexity, large focus on } \\
\text { continuous improvement and triple bottom line } \\
\begin{array}{l}\text { Domestic-level: strong reputation control in some } \\
\text { countries creating; laissez-faire approach in most } \\
\text { producing countries }\end{array}\end{array}$ \\
\hline $\begin{array}{l}\text { Upgrading } \\
\text { possibilities }\end{array}$ & $\begin{array}{l}\text { Limited; undifferentiated trade; however, } \\
\text { producing countries achieve product } \\
\text { valorisation through higher international } \\
\text { prices provided by the ICA }\end{array}$ & $\begin{array}{l}\text { Potentially increasing through marketing of } \\
\text { conscious coffee and direct e-commerce sales; } \\
\text { openings in specialty markets more suitable to } \\
\text { estates than smallholders }\end{array}$ & $\begin{array}{l}\text { Increasing through production of 'micro-lot' high- } \\
\text { quality coffee and participation in 'Cup of Excellence' } \\
\text { competitions; threat of market saturation similar to } \\
\text { certified coffees; emergence of micro-lot roasting at } \\
\text { origin for high-end consumption markets }\end{array}$ \\
\hline
\end{tabular}


Figure 1. Reorganization of the global coffee roasting sector, 1998-2016. Sources: Ponte (2002), Statista (2016), Grabs (2017). Adapted from Grabs (2018). 